when nearly flat; just as the caution in the acceptance of a theory which he feels called on to inculcate does not deter him from asserting as a fact that "our distant ancestors walked on all-fours." I took great pains to justify my opinion that, in walking, the toes should first touch the ground. Mr. Allen's letter may pass for a reply to arguments used in mine. As, however, the point involved has an important bearing on the question what proper walking is, it may be added that Professor Michael Foster, as I have since found, holds the same opinion, and that he has paid special attention to the point is shown by his qualifying a statement in the text, that the toe does first touch the ground, by a foot-note saying that this is rather as it should do. Very recently an intelligent engineer told me that the barefooted natives with whom he had been engaged in making a railway in Brazil put the front of the foot down first, and hardly touched the ground at all with the heel. These men, he said, were of Portuguese descent, and had exceedingly good feet. Moreover, it is difficult to imagine how Red Indians can walk with their toes turned in wards (whose walking Sir John Burgoyne said should be the model for our soldiers' march) if the heel be direeted downwards. So much for Nature. I hear on good anthority that high-class teachers of calisthenics in ladies' schools have long taught that in walking the toes should first touch the ground.

I am, Sir, yours truly,
Gloucester, August 18th, 1884.
$*^{*}$ Here the controversy must close. - ED. L.

\section{"BOGUS AMERICAN DEGREES."}

\section{To the Editor of THE LANCET.}

SrR,-I notice in your issue of August 16th an extract from The Times about the bogus M.D. of the University of Philadelphia. In this district and in the North of England generally, where collieries and ironworks exist, there the impostors of Philadelphia plant themselves, and are a curse to the unfortunate working class, whom they dupe.

I send you the original letter I received from the British consul at Philadelphia. Will you endeavour to bring it under the notice of the medical men in Parliament? Something ought to be done to stop this quackery.

I am, Sir, yours truly,

JoHN C. O'HANLON.

Tudhoe Grange, Spennymoor, Durham, Aug. 16th, 1884.

"British Consulate, Philadelphia, July 26th, 1884.

"SrR, -With reference to your letter of the 25 th ult., have to inform you that the University of Philadelphia is no longer in existence, its charter having been cancelled by the Government of Pennsylvania after a disgraceful existence of many years. Diplomas purporting to issue from such an institution are bogus and a fraud upon the community.

$$
\text { "Your obedient servant, }
$$

"Robert Charles Clipperton,

"John C. O'Hanlan, Esq., M.D.,
Tudhoe Grange, Spennymoor, Durham." Majesty's Consul.

\section{RUPTURE OF THE COVERINGS OF AN INGUINAL HERNIA.}

To the Editor of THE LANCET,

SIR, - I read with much interest in your last number the report of the case of rupture of the coverings of an inguinal hernia through the cicatrix of an old operation wound. In a similar case which I brought before the Medical Society last year, and which was reported at length in THE LANCET, the rupture occurred not through the cicatrix of the old operation wound, but through the sound skin, where it joined the cicatrix, and I should imagine this to be the most likely place for such a rupture to occur. I trust that in Mr. Keetley's case the statement made by the man of his treatment before reaching the hospital is not quite correctviz., that "he walked a quarter of a mile to see a surgeon, who wrapped a piece of lint round the part, and ordered him to go off to a hospital at;once; on leaving the surgery he walked back to the place where he left his waggon, and then took a cab to the hospital." Surely, no human being, still less a surgeon, would leave a man under such circumstances to shift. for himself.

I am, Sir, yours truly,

Harley-street, Aug. 19th, 1884.

\section{BIRMINGHAM.}

(From our own Correspondent.)

CHOLERA SCARES.

CoNSIDERABLE excitement was created in Birmingham on Tuesday by the prominence given by the press to the report that a death had occurred from Asiatic cholera. Carefal inquiry, however, leads to the belief that an error has been committed in supposing this to be the case. The patient was a man aged forty-seven, living in a densely populated part of the town; the seizure took place about midnight on the preceding Friday, the man having gone to bed in apparently good health. The next day he was able to be downstairs and about the house, but became worse in the evening from diarrhœa, stomachic pains, and cramp in various parts of the body. He was better again on the Monday, but on a return of the symptoms died from collapse at six o'clock in the evening, after an illness of fifty-six hours. An official examination, under the direction of the medical officer of health, has shown the case to have been one of severe diarrhoea and collapse. The prevalence of diarrhœe in the town at the present time is very great. From the 10th to the 17 th inst. 800 cases were treated at the General Hospital, and in one week at the Owens Hospital 490. In this instance the certificate of the medical man in attendance was filled up as "cholera" and "collapse." In the present state of public excitement on the question, it is incumbent upon medical practitioners to promote the confidence of the public, rather than to add to the apprehension which so many people have of this dread scourge. Judicions dealing with certificates of death, and careful comparison of known facts relative to the two diseases, will generally serve to distinguish between the true form of cholera and the more common cases of acute diarrhoea with collapse and cramps which occur in such frequency at this season of the year in all large towns, In the present case much need. less alarm has been caused, which it is to be hoped will be assuaged by the prudent and clear letter which the Mayor has written to the public papers on the question.

IRREGULARITY IN DEATH CERTIFICATES.

A case of much public importance was heard at the Birmingham Police-court on the 15th inst., upon a summons taken out by the Superintendent Registrar against a Mr. Williamson, a local medical practitioner, for giving a medical certificate of the cause of death of a child he had not seen or attended during illness. From the evidence it was shown that the child was attended by an unqualified assistant of the defendant's, the latter signing the certificate after the death of the child. Some contradictory evidence was given as to the genuineness of the certificate, but the magistrates considered the case proved, and imposed a mitigated penalty of $£ 5$ and costs or twenty-eight days imprisonment. It cannot be too widely known that such offences are punishable in a greater degree than this, for if proceeded against by indictment, a conviction renders the offender liable to two years' imprisonment with hard labour, or seven years' penal servitude. Irregularities of this kind open the door to serious abuses of many kinds, and it is to the interest of the profession, as well as to the security of the public, that they should | be protected from frauds of a similar character to this.

\section{IRELAND. \\ (From our oun Correspondent.)}

ROYAL COMMISSION ON IRISH PRISONS,

THE Commissioners appointed to inquire into the administration, discipline, and condition of prisons in Ireland, both local and convict, report that they have inspected carefully the convict prisons, the majority of the local prisons, and some bridewells. At these visits an examination was made as regards the general structure of the buildings, the wards, cells, stores, and hospitals; also, the sanitary and culinary arrangements, the provision for the supply of water, and that for exercise and labour. Many of the 